\title{
Synthesis and characterization of nanoarchitectures from fatty acid derivatives of 2,6-diaminopyridine and 2-aminopyridine
}

\author{
Mohammad F. Hassan • Abdul Rauf
}

Received: 1 April 2014/Accepted: 27 May 2014/Published online: 30 July 2014

(C) The Author(s) 2014. This article is published with open access at Springerlink.com

\begin{abstract}
The self-assembling property of lipids makes it an important building block in the field of supramolecular nanoarchitectures with a variety of applications in chemistry, biochemistry, materials science and medicine. We report here, the synthesis and formation of variety of nanostructures such as nanosheets, nanofibers and nanotubes of fatty acid derivatives of 2,6-diaminopyridine and 2-aminopyridine. These molecules possess a saturated or unsaturated long alkyl-chain group as the self-assembling unit. The molecular recognition property of diaminopyridine linker as a result of H-bonding was confirmed by ${ }^{1} \mathrm{H}-\mathrm{NMR}$ and fluorescence spectroscopy and it plays an important role in monitoring the chemical selectivity of supramolecular aggregates toward guest binding. The chemical structures were characterized by Fourier transform-infrared, ${ }^{1} \mathrm{H}-\mathrm{NMR},{ }^{13} \mathrm{C}$-NMR, mass spectra, whereas the morphologies were imaged using scanning electron microscopy and transmission electron microscopy.
\end{abstract}

Keywords Self-assembly $\cdot$ Fatty acids $\cdot$ Molecular recognition $\cdot$ SEM $\cdot$ TEM

\section{Background}

In the last two decades the nanotubes of many compounds, such as semiconductors, polymers, metals, oxides, sulphides, lipids, have been synthesized [1-4] and extensively investigated [5], but in recent years the formation of soft organic tubular structures from aggregation of conjugated

M. F. Hassan · A. Rauf ( $($ )

Department of Chemistry, Aligarh Muslim University,

Aligarh 202002, Uttar Pradesh, India

e-mail: abduloafchem@gmail.com molecular species has attracted attention in nanoscience research field since it may find applications in catalysis, drug delivery, selective separations sensors and conducting devices in nano-, opto- or ionic electronics. Several class of organic systems are known to provide tubular structures including lipid [6, 7], steroidic [8, 9] and peptidic [10] systems. Cardanols, an example of sugar-lipid conjugate, consists of a carbohydrate head group and an aliphatic alkyl chain connected through a phenyl moiety. When dispersed in aqueous solution at room temperature, this material forms fibrous aggregation and nanotubular structures [11]. Although related literature on further practical application of cardanol-based glycolipids is absent, its selfassembling properties have promoted the synthesis of several glycolipids such as monosaccharide esters with diamino-aromatic linkers [12], amygdalin-based esters [13] and dialkanoate derivative of sugar alcohols [14]. Unlike the carbon nanotubes (CNTs), organic nanotubes have excellent dispersibility in water and incorporate guest substance of over $10 \mathrm{~nm}$ in size, such as nucleic acids and proteins [15]. The organic nanotubes can provide suitable hollow cylindrical space for biomacromolecules that are at least 10 times larger in dimension as compared to macrocylic molecules used for host-guest study [16]. Because of the confined nanospace, lipid nanotubes (LNTS) have found potential in chemical and biological applications [17-23], including controlled drug release [19-22] and artificial chaperoning of denatured protein [23]. Lipid nanotube was used as template for the synthesis of titania, tantalum oxide and vanadium oxide nanotubes [24]. These transition metal oxide nanotubes find potential applications in gas sensors, photo catalysts, environmental purification and high-effect solar cells [25-28]. Keeping in mind the importance of aforementioned self-assembled nanoaggregates, in this paper we focus our attention on the creation of 
a scaffold that may be easily form aggregates in aqueous solution. By synthesizing and self-assembling of a series of long-chain fatty acids derivatives of 2,6-diaminopyridine and 2-aminopyridine, we generated a number of products ranging from nanosheets, fibers to tubes. The presence of hydrophobic chain of fatty acid particularly, from both ends of the pyridine-nucleus enhances self-assembly through van der Waal interactions. We characterized the morphologies of these nanoassemblies on the basis of transmission electron microscopy (TEM), scanning electron microscopy (SEM) and FT-IR and their molecular recognition by ${ }^{1} \mathrm{H}-\mathrm{NMR}$ and fluorescence spectra.

\section{Results and discussion}

A series of compounds $(\mathbf{3 a}-\mathbf{c}, \mathbf{6} \mathbf{a}-\mathbf{b}, \mathbf{8})$ were synthesized from 2,6-diaminopyridine (1) and 2-aminopyridine (7) and corresponding acid chlorides $(\mathbf{2} \mathbf{a}-\mathbf{c}, \mathbf{4 a}-\mathbf{b})$ in dry conditions as shown in (Schemes 1, 2, 3). The selfassembly of the series of compounds $(\mathbf{3 a}-\mathbf{c}, \mathbf{6 a}-\mathbf{b}, \mathbf{8})$ occurs rapidly under mild conditions. All these compounds form typical nanoassemblies in a mixture of water and methanol $(1: 1, \mathrm{~V} / \mathrm{V})$. To characterize the morphologies of nanoassemblies, the structures were observed using TEM and SEM. The TEM and SEM of compounds $(3 \mathbf{a}-\mathbf{c}, \mathbf{6 a}-\mathbf{b}, \mathbf{8})$ in aqueous solution are represented by (Fig. 1a-i) and (Fig. 2a-d), respectively. TEM and SEM revealed that self-assembled molecular objects from compounds 3a, 6a and $\mathbf{6 b}$ gave nanotube structures as a major product $(\sim 80 \%)$ (Fig. 1a-e) with nanosheets as minor product $(\sim 20 \%)$ (Fig. $2 \mathrm{c})$. The TEM image of $3 \mathbf{a}$ show that it forms nanotubes with nearly $250 \mathrm{~nm}$ diameter and length in the range of $2-8 \mu \mathrm{m}$ (Fig. 1a-b) while nanotubes derived from 6 a have length of nearly $3.5 \mu \mathrm{m}$ and wider diameter of $(<300 \mathrm{~nm})$ approximately
(Fig. 1c). In particular, the compound $\mathbf{6 b}$ proved to self-assemble into nanotubular structure exclusively. Figure 1d-e shows the typical morphologies of sample obtained from different concentration of $\mathbf{6 b}$. The initial concentration of $3.7 \times 10^{-3} \mathrm{M}$ of $\mathbf{6 b}$ results in the formation of nanotubes of size in the range of about 100-500 nm (Fig. 1d). An increase in the concentration to $9 \times 10^{-3} \mathrm{M}$ changes the dimension of nanotubes having length 1-1.5 $\mu \mathrm{m}$ and diameter 100-150 nm (Fig. 1e). The compounds $\mathbf{3 b}$ and $\mathbf{3 c}$ were found to self-assemble into curled nanosheets (Fig. 2a) and nanofibers with length of nearly 70-200 $\mu \mathrm{m}$ (Fig. 1f-i). Lipid 8 instead of curled sheets, gave a very thin and flat nanosheet structures (Fig. 2b, d). The image of the above compounds indicates that morphologies of nanoassemblies depend on the saturated or unsaturated nature of alkyl chain. The compounds 3a, 6a and $\mathbf{6 b}$ with unsaturated alkyl moiety selfassembled into tubular structures while the compounds $\mathbf{3 b}$ and 3c possessing saturated alkyl chain resulted into nanofibers. Hence, unsaturated oleic moiety appears to be critical in nanotube formation. The literature survey [2933] reveals that tube-forming self-assembled molecular species requires unsaturation in the lipophilic moiety although, the evidence is limited. A recent study [34, 35] of cardanol-based glycolipid also shows that glycolipid with unsaturated chain self-assembled into coiled or tubular structures by non-parallel chiral packing due to kink into alky chain's structure expressed by the cisdouble bond of the monoene, while the saturated analogue self-assembled into twisted fibers through parallel chiral packing. Based on our results from TEM and SEM images of compounds $\mathbf{3 a}-\mathbf{b}$ and $\mathbf{6} \mathbf{a}-\mathbf{b}$, a molecular packing motif is proposed in (Fig. 3). In spite of the extensive theoretical and experimental work [36-39], several questions remain to be answered about the mechanism or pathway involved in the tube formation. However, the driving
Scheme 1 Synthetic route to 3a-c, Reaction of $\mathbf{1}(2.5 \mathrm{~mm})$ with $2 \mathbf{a}-\mathbf{c}(5 \mathrm{~mm})$ and $\mathrm{Et}_{3} \mathrm{~N}$ $(5 \mathrm{~mm})$ in THF $(50 \mathrm{~mL})$ at RT

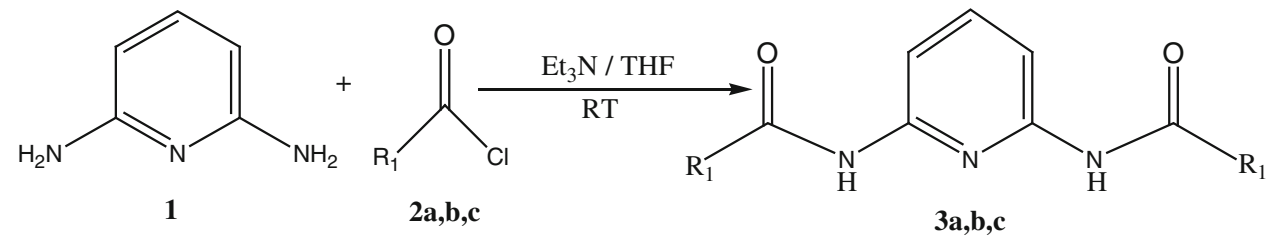

3a,b,c

Compound


Scheme 2 Synthetic route to $\mathbf{6 a}-\mathbf{b}$, (i) Reaction of $\mathbf{1}(5 \mathrm{~mm})$ with $4 \mathbf{a}, \mathbf{b}(5 \mathrm{~mm})$ and $\mathrm{Et}_{3} \mathrm{~N}$ $(5 \mathrm{~mm})$ in THF $(50 \mathrm{~mL})$ at $\mathrm{RT}$, (ii) Reaction of $\mathbf{5 a}, \mathbf{b}(5 \mathrm{~mm})$ with $2 \mathbf{a}(5 \mathrm{~mm})$ and $\mathrm{Et}_{3} \mathrm{~N}$ $(5 \mathrm{~mm})$ in THF $(50 \mathrm{~mL})$ at $\mathrm{RT}$<smiles>[R1]C(=O)Nc1cccc(CC([R17])N(C)C)n1</smiles>

$5 \mathbf{a}, \mathbf{b}$<smiles>[R]C(=O)Nc1cccc(NC([R])=O)n1</smiles>

Compound

Scheme 3 Synthetic route to 8 , Reaction of 7 ( $5 \mathrm{~mm})$ with $\mathbf{2 b}$ $(5 \mathrm{~mm})$ and $\mathrm{Et}_{3} \mathrm{~N}(5 \mathrm{~mm})$ in THF (50 $\mathrm{mL})$ at RT<smiles>Nc1ccccn1</smiles>

7<smiles>[R]C(=O)Cl</smiles>

$2 \mathbf{b}$<smiles>[R17]CCNC([R1])=O</smiles>

8

$\frac{\text { Compound }}{\mathbf{2 b}, \mathbf{8}}$

forces that put the building blocks (self-assemblies) into a well-defined nanoarchitecture can be understood and elaborated by many workers [40-50]. The organization of building blocks into ordered structures is facilitated by a combination of many different non-covalent interactions such as H-bonding, Pi-Pi stacking and hydrophobic interactions. In 2,6-diaminopyridine-fatty acid system, the amide group can facilitate the stacking of molecules through $\mathrm{H}$-bonding, the pyridine ring moiety can facilitate intermolecular interactions through stacking and the hydrophobic hydrocarbon chain of fatty acid not only decreases the solubility in water but also helps the molecular association through the van der Waals interactions. These groups together can synergistically act to form strong intermolecular interactions, which lead to tubular or fibrous structures (Fig. 4b). Besides these nanotubular or fibrous structures, nanosheets were also formed during earlier stage of assembling process. These nanosheets are assumed to be 

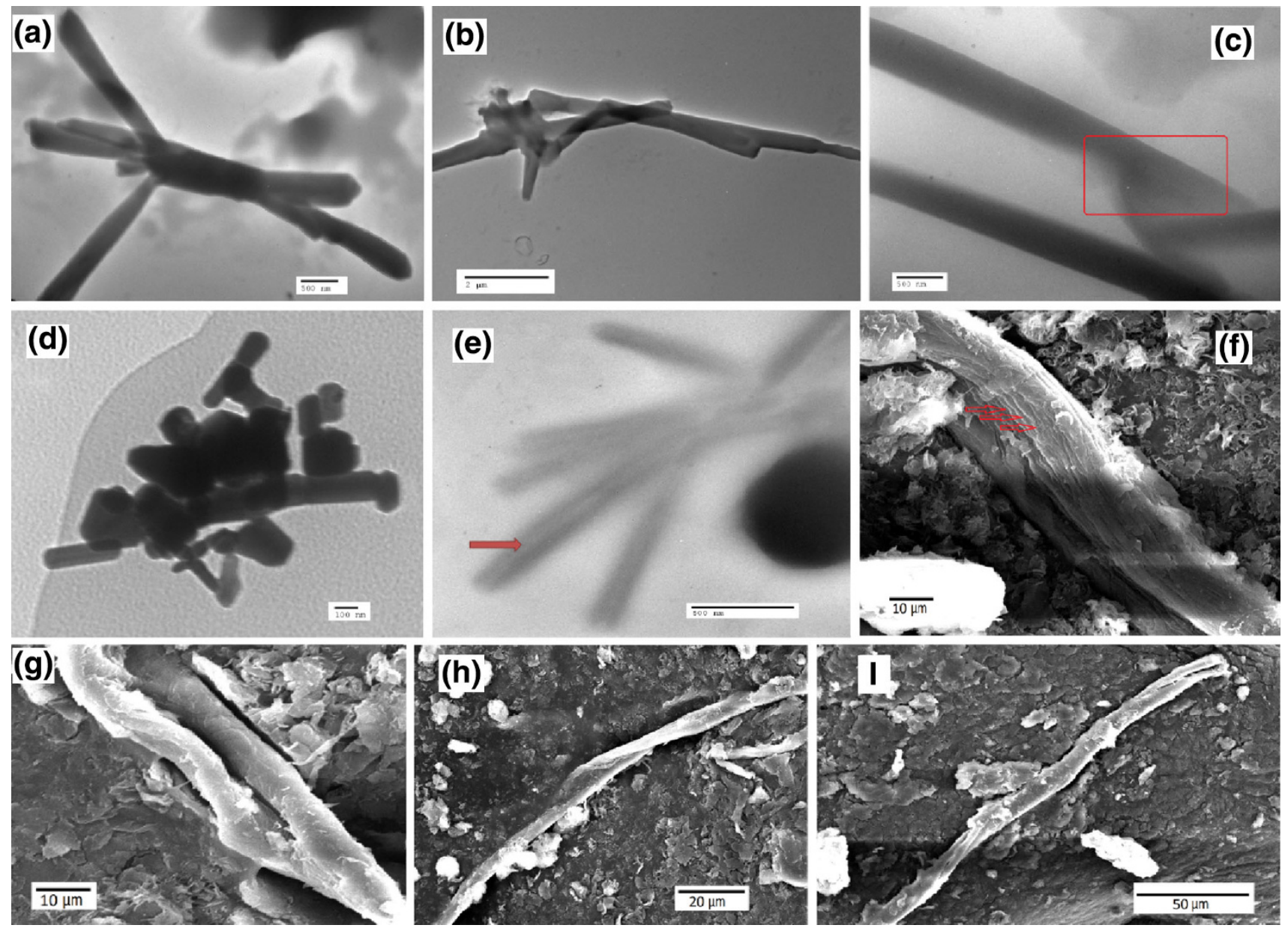

Fig. 1 TEM images of self-assembled morphologies; (a, b) 3a (nanotube), (c) 6a (nanotube showing cylindrical hollow portion, marked by red line), $(\mathbf{d}, \mathbf{e}) \mathbf{6 b}$ (nanotube, red arrow indicates central

cavity). SEM images of $\mathbf{3 b}$-c; (f) $\mathbf{3 b}$ (a developing nanofiber showing multilayer morphology), (g) 3b (nanofiber) (h) 3c (twisted nanofiber), (i) $3 \mathbf{c}$ (two nanofibers warped into each other)

as templates for the formation of 3D-structures (nanotubes) similar to the formation of polyaniline nanotubes from aniline oligomeric sheets based on a rolling-up mechanism [51]. A similar mechanism was also used to explain the formation of tubular structures by self-assembly of diphenylalanine [52] and formation of multi- and single-walled CNTs $[53,54]$. The driving force of rolling behavior can be attributed to minimizing of surface energy. An example of the rolling of a nanosheet into a nanotube is shown in Fig. 4. The evidence of rolling of nanosheet into a nanotube comes from its reverse process that is, tube-to-sheet conversion which is observed in multilayer $\mathrm{VO}_{x}$ nanotubes under solvothermal-induced conditions [55] or, in case of multiwalled carbon nanotubes (MWCNTs) induced by solutionbased oxidation [56]. The irregular partially curled nanosheet structure (Fig. 2a) is more likely to act as templates for nanofibers. These 2D-nanosheets from saturated analogue of DAP stacked together to give multilayered nanofibers (Fig. 1f) very similar to the case observed in hexakis (alkoxy) triphenylene nanosheets [57].

\section{FT-IR study}

Fourier transform-infrared (FT-IR) of self-assembled compounds (3a, 3b, 6a and $\mathbf{8}$ ) is shown in Fig. 5. The observed $(\mathrm{C}-\mathrm{H})$ stretching peaks, $2,920.8$ and $2,850 \mathrm{~cm}^{-1}$ of $\mathbf{3 b}$ are comparatively less than $(\mathrm{C}-\mathrm{H})$ stretching patterns 2,921.7, 2,854.5 $\mathrm{cm}^{-1}$ and 2,925, 2,854.2 $\mathrm{cm}^{-1}$ of $\mathbf{3 a}$ and 6a, respectively. Further, the amide $(\mathrm{C}-\mathrm{O})$ stretching peak $1,666.7 \mathrm{~cm}^{-1}$ of $\mathbf{3 b}$ was also less than the observed amide (C-O) peaks $1,671.3$ and $1,670.8 \mathrm{~cm}^{-1}$ for $\mathbf{3 a}$ and $\mathbf{6 a}$, respectively (Fig. 5). The comparatively less stretching pattern of $(\mathrm{C}-\mathrm{H})$ and $(\mathrm{C}-\mathrm{O})$ groups of $\mathbf{3 b}$ than that of $\mathbf{3 a}$ and $6 \mathbf{a}$ indicate a more ordered and crystalline packing of $\mathbf{3 b}$ in comparison to $\mathbf{3 a}$ and $\mathbf{6 a}$ which are consistent with high order crystalline nanofibers derived from $\mathbf{3 b}$. Most probably, the kink in the self-assembled structures from 3a and $6 \mathbf{a}$ increases the stretching value of $(\mathrm{C}-\mathrm{H})$ and $(\mathrm{C}-\mathrm{O})$ groups there by reducing the crystallinity of the nanostructure and enabling more facile formation of nanotubes. It is more probable that one-sided H-bonding and weak 

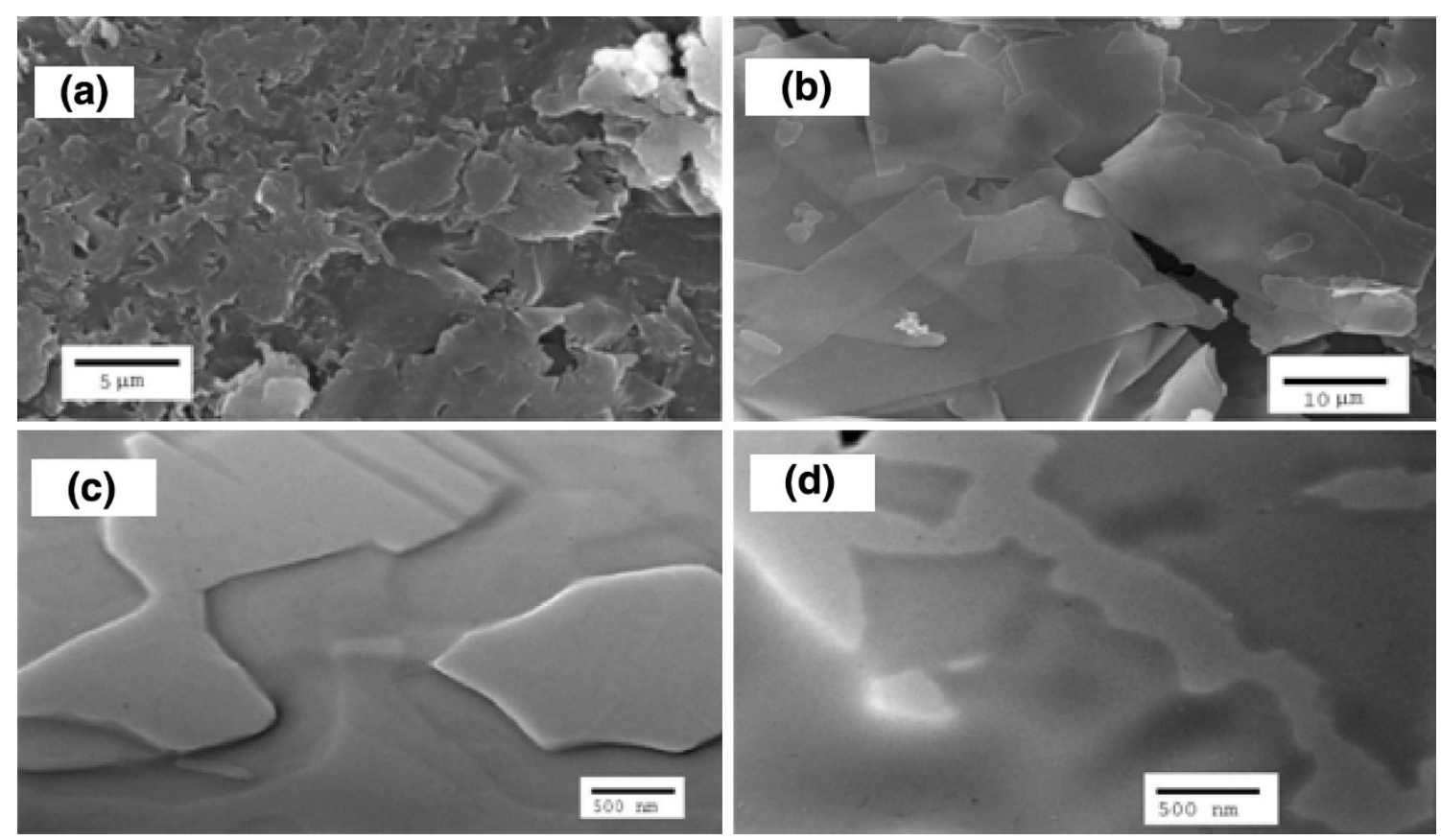

Fig. 2 SEM images of lipid nanoassemblies; (a) 3b (curled nanosheets), (b) 8 (flat nanosheets). TEM images; (c) 6a (nanosheets), (d) 8 (nanosheets)

\section{Fig. 3 Schematic}

representation of proposed selfassembled nanostructures from $\mathbf{3 b}$ and 3a with a) saturated and b) unsaturated alkyl chains (the alkyl chain does not represent the exact numbers of carbons, it is only representative). The cisgeometry of double bond in $\mathbf{3 a}$ results in a kink and slightly less layered interdigitation
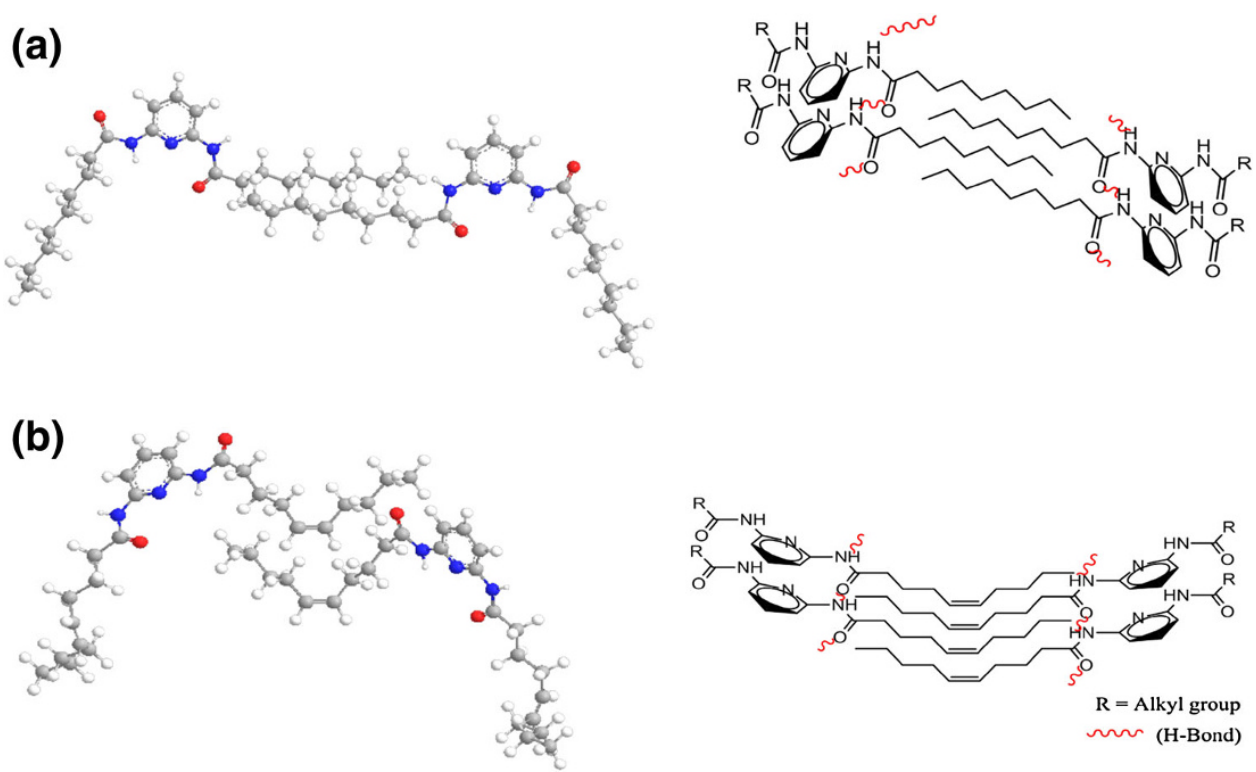

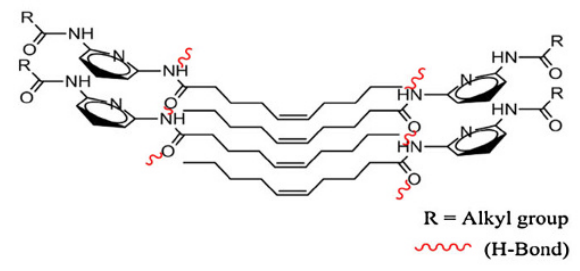

hydrophobic interactions of $\mathbf{8}$ causes less order molecular packing which is indicated by its higher stretching pattern $2,925,2,854.2$ and $1,687.5 \mathrm{~cm}^{-1}$.

\section{Molecular recognition study}

Diaminopyridine derivatives are known to function as artificial receptors that can bind various ligands through complementary multiple H-bonding [58]. Hence a DAPlinker could serve as functional recognition element for
H-bonding and due to this, in the process of its binding with external ligands its intrinsic spectra would be effected. To prove this fact, we selected succinimide (S) as external ligand because of its complimentary H-bonding capability to the DAP group and examined the ${ }^{1} \mathrm{H}-\mathrm{NMR}$ of stoichiometric (1:1) mixture of compound 3a and $\mathbf{S}$ in $\mathrm{CDCl}_{3}$ (Fig. 6). It was found that amide $\mathrm{N}-\mathrm{H}$ of 3a shifted downfield from 7.60 to $8.44 \mathrm{~Hz}$ and the imide $\mathrm{N}-\mathrm{H}$ of $\mathbf{S}$ from 8.89 to $10.20 \mathrm{~Hz}$ as shown in (Fig. 6). These downfield shifts upon combination of $\mathbf{3 a}$ and $\mathbf{S}$ confirm the presence of strong (3-point) H-bonding 
Fig. 4 a TEM micrograph of rolling of a thin nanosheet into nanotube, b Schematic representation of sheet-to-tube conversion and various noncovalent interactions which provided stabilization to the nanostructures

\section{(a)}

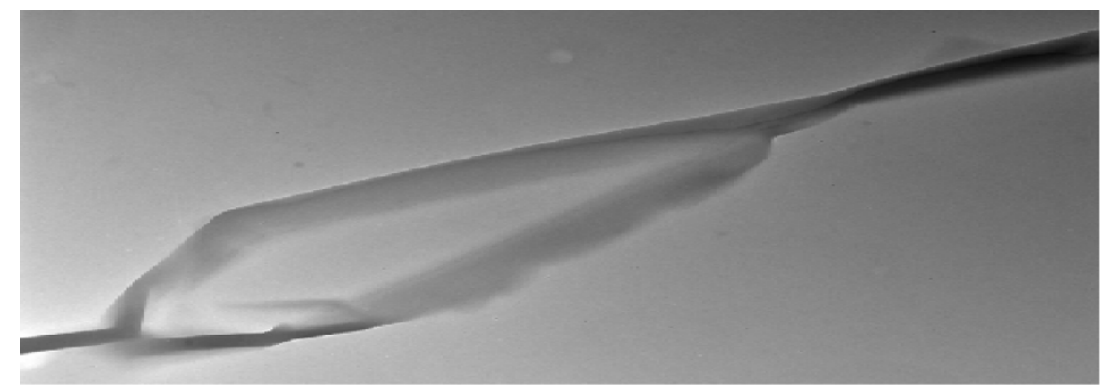

(b)
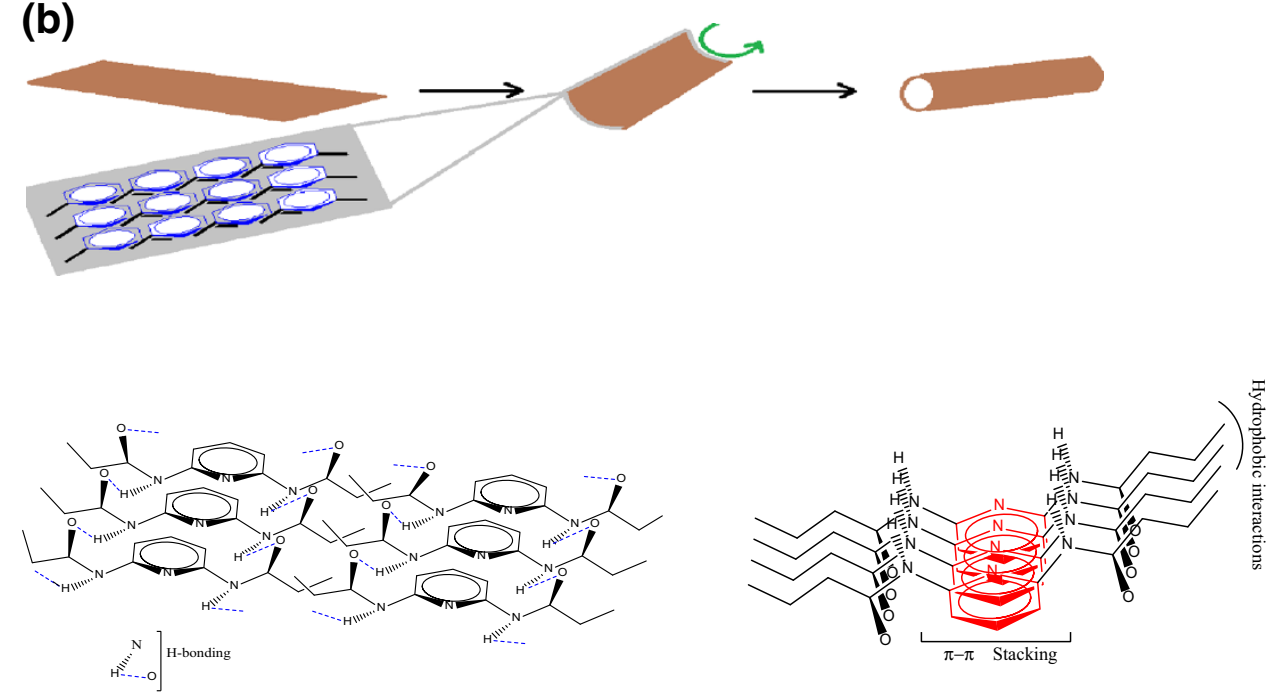

interaction between amide N-H's of 3a and carbonyl C-O of $\mathrm{S}$ and imide $\mathrm{N}-\mathrm{H}$ and aromatic ring nitrogen of $\mathbf{S}$ and 3a, respectively. We further confirmed the DAP-linker as a recognition site for multiple H-bonding by observing fluorescence quenching. As shown in (Fig. 7), the addition of increasing quantities of $\mathbf{S}$ as external ligand to the compounds $\mathbf{3 b}, \mathbf{6 a}$ and $\mathbf{8}$ increased the observed fluorescence quenching there by indicating that $\mathrm{H}$-bonding interactions between compounds $\mathbf{3 b}, \mathbf{6 a}$ and $\mathbf{8}$ with $\mathbf{S}$. Such type of quenching is also observed in other compounds $[12,59]$.

\section{Conclusions}

A series of fatty acid-based self-assembled compounds were formed in good yield by simple one-pot synthesis involving the addition of long fatty acid chain to the 2,6diaminopyridine and 2-aminopyridine moiety. By utilizing basic self-assembly properties of these compounds, a range of soft nanomaterials such as nanosheets, nanotubes and nanofibers were generated. The FT-IR studies confirm the presence of a highly ordered structure in the aliphatic region via van der Waals interactions. The SEM and TEM images study has demonstrated that, nanostructures derived from $N, N^{\prime}$-diacyl-2,6-diaminopyridine depends on the unsaturation of alkyl chain. The formation of tubular structures by rolling of nanosheet is confirmed through TEM image.

\section{Methods}

\section{Materials}

(9Z)-octadec-9-enoic (oleic), undec-10-enoic, octadecanoic (stearic) and hexadecanoic (palmitic) acids were purchased from fluka chemicals (Buck: Switzerland). 2-aminopyridine, 2,6-diaminopyridine, triethyl amine were purchased from Merck, Mumbai, India. Succinimide was purchased from (Sigma-Aldrich, India). Thin layer chromatography (TLC) was done on thin glass plates $(20 \times 5 \mathrm{~cm})$ with a layer of silica gel $\mathrm{G}$ (Merck, Mumbai, India, $0.5 \mathrm{~mm}$ thickness). Mixtures of petroleum ether-diethyl ether-acetic acid $(70: 30: 1 ; \mathrm{v} / \mathrm{v})$ were used as developing solvent for TLC. The column chromatography was carried out with silica gel (Merck, Mumbai, India, 60-120 mesh). Abbreviation ' $\mathrm{mm}$ ' stands for milli mole. 
(a)

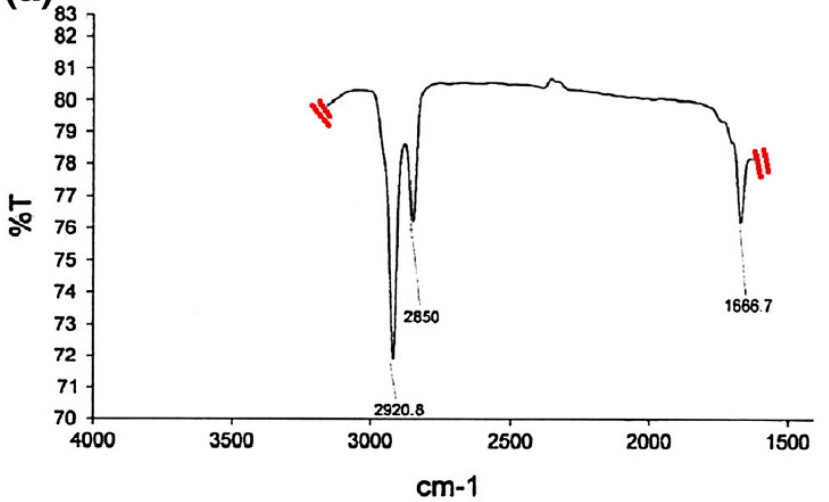

(c)

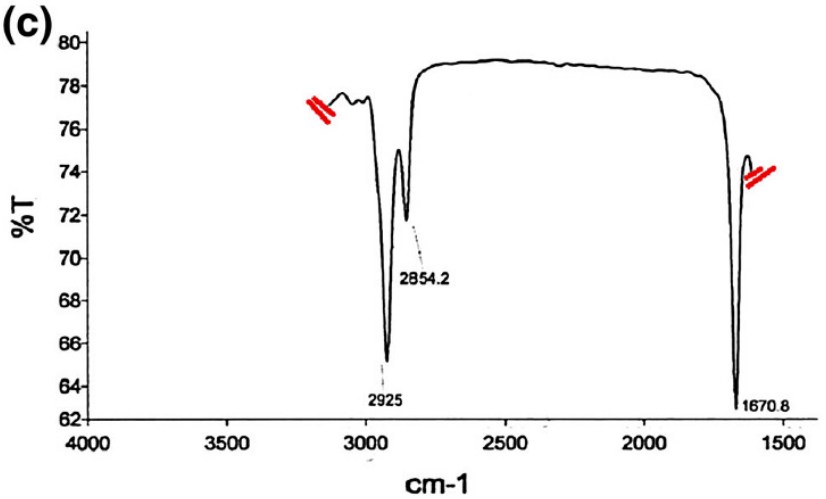

(b)

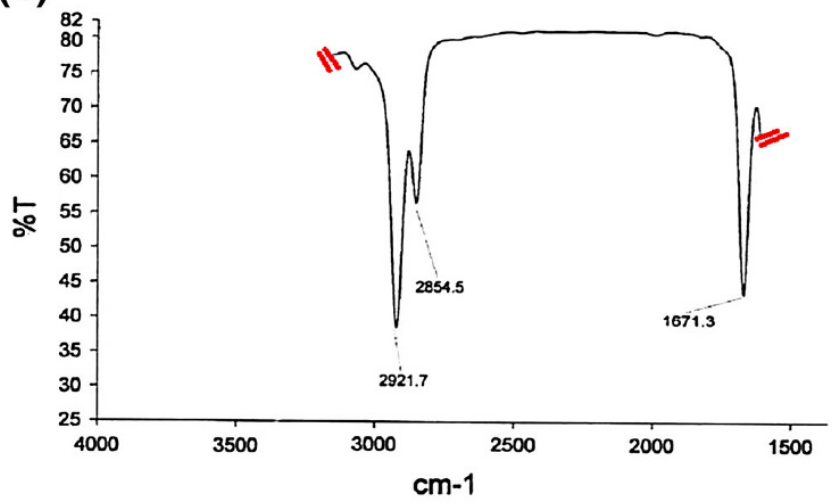

(d)

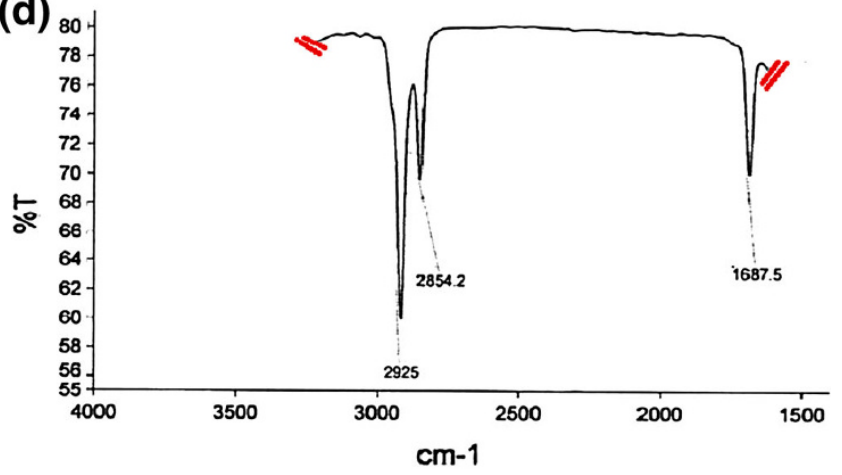

Fig. 5 FT-IR of self-assembled compounds; (a) 3b, (b) 3a, (c) 6a, (d) 8

Fig. $6{ }^{1} \mathrm{HNMR}$ spectra of NHS of $N, N^{\prime}$-(Pyridine-2,6diyl)bis(octadec-9-enamide), 3a and $\mathbf{S}$ in $\mathrm{CDCl}_{3}$; (a) $\mathbf{3 a}$, (b) $\mathbf{S}$, (c) Stoichiometric 1:1 mixture of $\mathbf{3 a}+\mathbf{S}$. The NH protons are indicated by alphabets $\mathrm{A}$ and $\mathrm{B}$

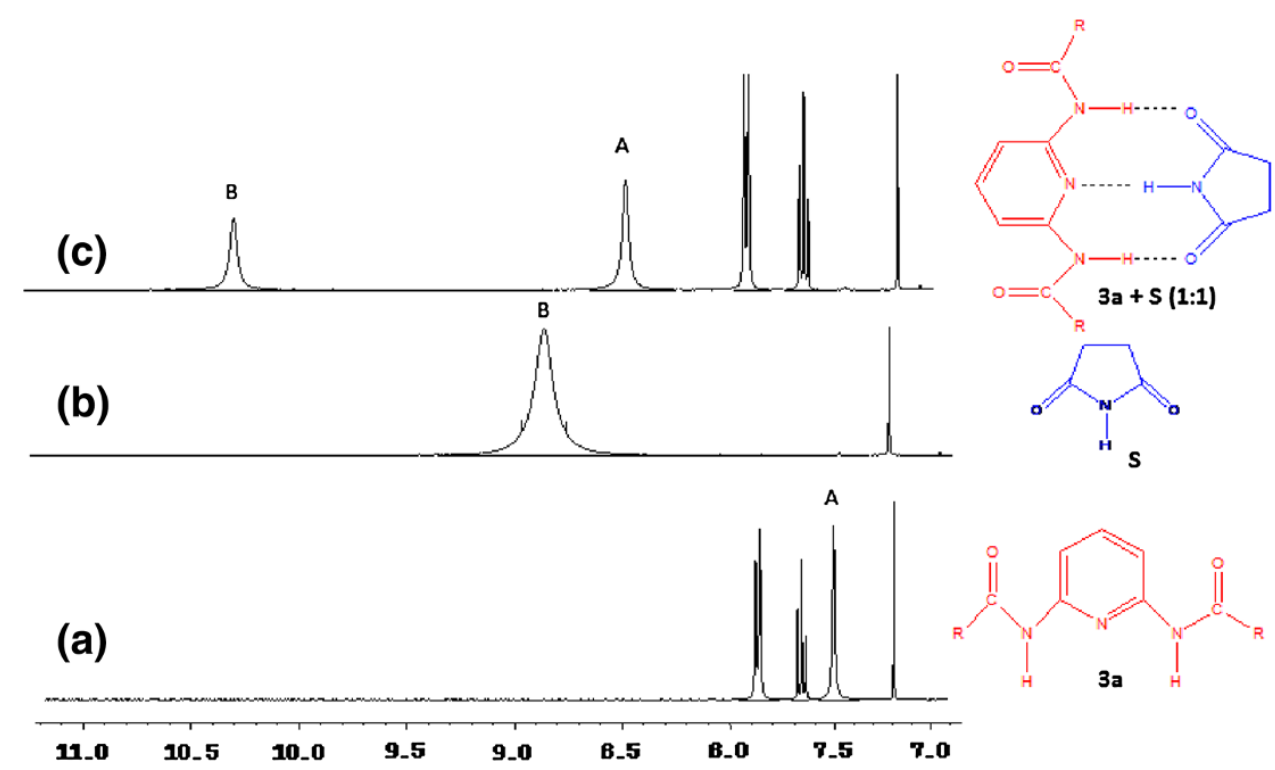

\section{Synthesis procedure}

Synthesis of $(3 a-c)$

A typical process involves the addition of corresponding oleoyl chloride (2a), stearoyl chloride (2b) and palmitoyl chloride $(\mathbf{2 c})(5 \mathrm{~mm})$ in dry THF $(10 \mathrm{~mL})$ to the stirred solution of 2,6-diaminopyridine (1) $(2.5 \mathrm{~mm})$ and triethylamine $(5 \mathrm{~mm})$ in dry THF $(50 \mathrm{~mL})$. The reaction mixture was stirred overnight at room temperature (Scheme 1). The progress of reaction was monitored by TLC. After completion of reaction, the reaction mixture was concentrated 

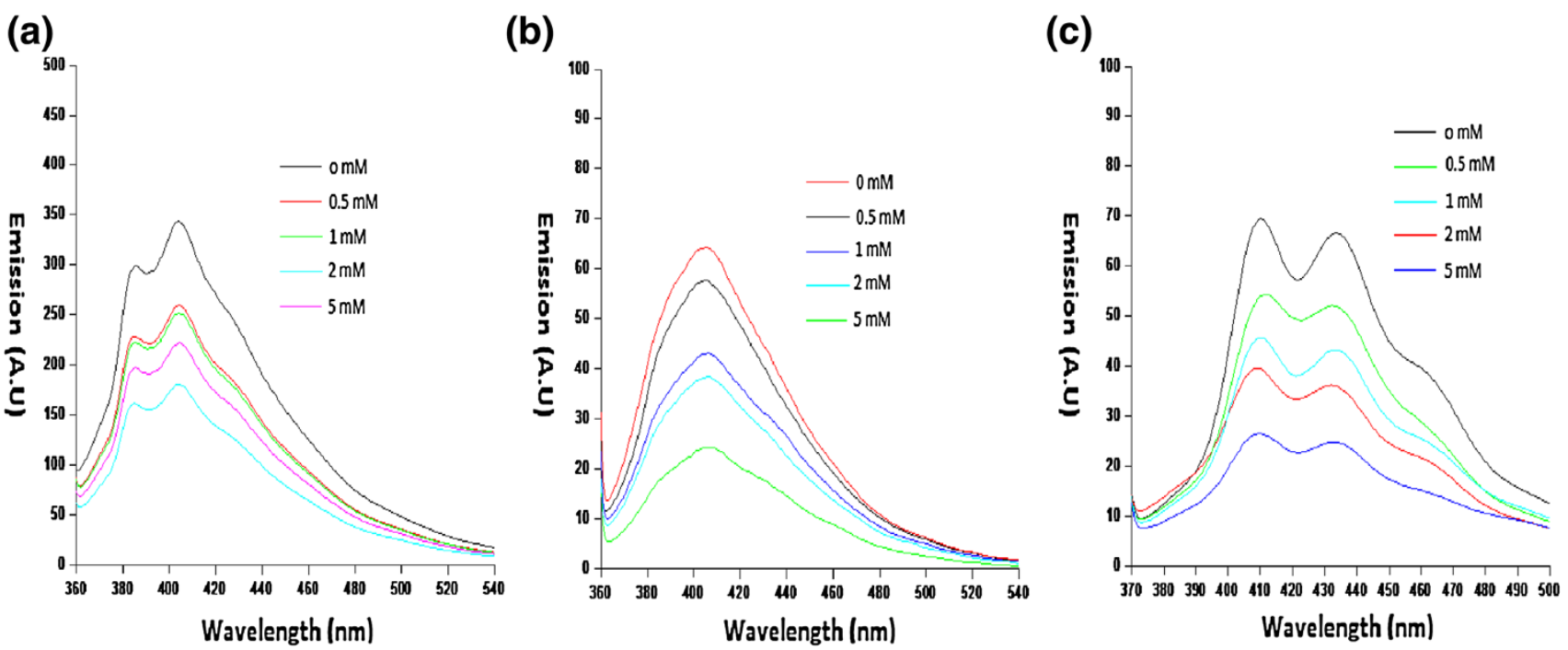

Fig. 7 Fluorescence quenching of a) $\mathbf{3 b}$, b) $\mathbf{6 a}$, and c) $\mathbf{8}\left(2 \times 10^{-5} \mathrm{M}\right.$ each) by $\mathbf{S}$ in $\mathrm{CHCl}_{3}$. The $\mathbf{S}$ concentration ranged from (top to bottom) 0 to $5 \mathrm{mM}$. Excitation was at $350 \mathrm{~nm}$

in vacuum and dissolved in dichloromethane $\left(\mathrm{CH}_{2} \mathrm{Cl}_{2}\right)$. The organic layer was washed with water $(3 \times 100 \mathrm{~mL})$ and dried over anhydrous sodium sulphate. The isolated crude products $(\mathbf{3 a}-\mathbf{c})$ were further purified by column chromatography using mixture of $n$-hexane-ethyl acetate (92:8, V/V) as eluent. All these compounds were characterized by their spectral data.

\section{$N, N^{\prime}$-(Pyridine-2,6-diyl) bis (octadec-9-enamide) (3a)}

White solid, yield $=70 \%$, m.p. $=93-95{ }^{\circ} \mathrm{C}$, IR $(\mathrm{KBr}$, $\left.\mathrm{cm}^{-1}\right): 3,305,2,924,2,857,1,667,1,587,1,527 .{ }^{1} \mathrm{H}$ NMR $\left(400 \mathrm{MHz}, \mathrm{CDCl}_{3}, \delta_{\mathrm{H}}\right): 7.91(\mathrm{~d}, 2 \mathrm{H}, J=8.0 \mathrm{~Hz}), 7.70(\mathrm{t}$, $1 \mathrm{H}, J=8.0 \mathrm{~Hz}), 7.60(\mathrm{~s}, 2 \mathrm{H}, \mathrm{NH}), 5.36(\mathrm{~m}, 2 \mathrm{H}$, $-\mathrm{CH}=\mathrm{CH}-), 2.37\left(\mathrm{t}, 4 \mathrm{H}, J=7.4 \mathrm{~Hz}, \mathrm{CH}_{2}-\mathrm{CO}\right), 2.0(\mathrm{~m}$, $\left.8 \mathrm{H},-\mathrm{CH}_{2}-\mathrm{CH}=\mathrm{CH}_{-} \mathrm{CH}_{2}-\right), 1.72\left(\mathrm{~m}, 4 \mathrm{H}, \mathrm{CH}_{2}-\mathrm{CH}_{2}-\mathrm{CO}\right)$, 1.29 (br.s, 44H, chain- $\mathrm{CH}_{2}$ ), 0.89 (dist.t, 6H, terminal$\left.\mathrm{CH}_{3}\right) .{ }^{13} \mathrm{C} \mathrm{NMR}\left(\mathrm{CDCl}_{3}\right.$, Proton decoupled, $\left.\delta_{\mathrm{C}}\right): 171.50$ $149.44,140.85,130,129.70,109.36,37.86,31.90,29.45$, 27.23, 25.33, 22.68, 14.11. ESI/MS $(\mathrm{m} / z):(\mathrm{M}+\mathrm{H})^{+}$calcd. For $\mathrm{C}_{41} \mathrm{H}_{71} \mathrm{~N}_{3} \mathrm{O}_{2}$ : 638.974; Found: 638.7

\section{$N, N^{\prime}$-(Pyridine-2,6-diyl) bis (octadecanamide) (3b)}

White solid, yield $=77 \%$, m.p. $=98-99{ }^{\circ} \mathrm{C}$, IR $(\mathrm{KBr}$, $\left.\mathrm{cm}^{-1}\right): 3,329,2,920,2,849,1,670,1,587,1,523 .{ }^{1} \mathrm{H}$ NMR $\left(400 \mathrm{MHz}, \mathrm{CDCl}_{3}, \delta_{\mathrm{H}}\right): 7.89(\mathrm{~d}, 2 \mathrm{H}, J=8.0 \mathrm{~Hz}), 7.69(\mathrm{t}$, $1 \mathrm{H}, J=8.0 \mathrm{~Hz}$ ), 7.55 (br.s, $2 \mathrm{H}, \mathrm{NH}), 2.37$ (t, $4 \mathrm{H}$, $\left.J=7.5 \mathrm{~Hz}, \mathrm{CH}_{2}-\mathrm{CO}\right), 1.70\left(\mathrm{~m}, 4 \mathrm{H}, \mathrm{CH}_{2}-\mathrm{CH}_{2}-\mathrm{CO}\right), 1.31$ (br.s, 56H, chain- $\mathrm{CH}_{2}$ ), 0.87 (dist.t, 6H, terminal $-\mathrm{CH}_{3}$ ). ${ }^{13} \mathrm{C} \mathrm{NMR}\left(\mathrm{CDCl}_{3}\right.$, Proton decoupled, $\left.\delta_{\mathrm{C}}\right): 171.60,149.48$, 140.82, 109.33, 37.89, 31.94, 29.71, 29.68, 29.62, 29.47,
$29.37,29.21,25.35,22.70, \quad 14.14$. ESI/MS $(m / z)$ : $(\mathrm{M}+\mathrm{H})^{+}$calcd. For $\mathrm{C}_{41} \mathrm{H}_{75} \mathrm{~N}_{3} \mathrm{O}_{2}$ : 643.002; Found: 643.7

$N, N^{\prime}$-(Pyridine-2,6-diyl) bis (hexadecanamide) (3c)

White solid, yield $=68 \%$, m.p. $=95-96{ }^{\circ} \mathrm{C}$, IR $(\mathrm{KBr}$, $\left.\mathrm{cm}^{-1}\right): 3,317,2,920,2,849,1,674,1,587,1,523 .{ }^{1} \mathrm{H}$ NMR $\left(400 \mathrm{MHz}, \mathrm{CDCl}_{3}, \delta_{\mathrm{H}}\right): 7.91(\mathrm{~d}, 2 \mathrm{H}, J=8.0 \mathrm{~Hz}), 7.71(\mathrm{t}$, $1 \mathrm{H}, J=8.0 \mathrm{~Hz}), 7.74(\mathrm{~s}, 2 \mathrm{H}, \mathrm{NH}), 2.38(\mathrm{t}, \quad 4 \mathrm{H}$, $\left.J=7.5 \mathrm{~Hz}, \mathrm{CH}_{2}-\mathrm{CO}\right), 1.73\left(\mathrm{~m}, 4 \mathrm{H}, \mathrm{CH}_{2}-\mathrm{CH}_{2}-\mathrm{CO}\right), 1.32$ (br.s, $48 \mathrm{H}$, chain- $\mathrm{CH}_{2}$ ), 0.90 (dist.t, $6 \mathrm{H}$, terminal- $\left.\mathrm{CH}_{3}\right) .{ }^{13} \mathrm{C}$ NMR $\left(\mathrm{CDCl}_{3}\right.$, proton decoupled, $\left.\delta_{\mathrm{C}}\right)$ : 171.56, 149.45, 140.80, 109.31, 37.77, 31.92, 29.73, 29.64, 29.33, 25.37, 22.65, 14.10. ESI/MS $(\mathrm{m} / \mathrm{z}):(\mathrm{M}+\mathrm{H})^{+}$calcd. For $\mathrm{C}_{37} \mathrm{H}_{67} \mathrm{~N}_{3} \mathrm{O}_{2}$ : 586.902; Found: 586.7

Synthesis of $(\mathbf{6 a}-\mathbf{b})$

These compounds were prepared by two step acylation of 2,6-diaminopyridine. A typical process involves the addition of acetyl chloride (4a) $(5 \mathrm{~mm})$ or 10 -undecenoyl chloride $(4 \mathrm{~b})(5 \mathrm{~mm})$ in dry THF $(10 \mathrm{~mL})$ to the stirred solution of $1(5 \mathrm{~mm})$ and triethylamine $(10 \mathrm{~mm})$ in dry THF $(50 \mathrm{~mL})$. The reaction mixture was stirred overnight at room temperature to form corresponding monoacyl derivatives of 2,6-diaminopyridine. The second step involves the addition of $\mathbf{2 a}(5 \mathrm{~mm})$ dissolved in $\mathrm{THF}$ (10 $\mathrm{mL})$ to the N-monoacyl -2,6-diaminopyridine (5a or 5b) solution (Scheme 2). The reaction mixture was stirred continuously till the end (monitored by TLC) to obtained the desired products in good yield, which were further purified by column chromatography using mixture of 
$n$-hexane-ethyl acetate $(90: 10, \mathrm{~V} / \mathrm{V})$ as eluent and characterized by spectral data.

\section{$N$-(6-Methanamidopyridine-2-yl) octadec-9-enamide (6a)}

Pale yellow solid, yield $=60 \%$, m.p. $=89-92{ }^{\circ} \mathrm{C}$, IR $\left(\mathrm{KBr}, \mathrm{cm}^{-1}\right): 3,317,2,924,2,853,1,674,1,587,1,527 .{ }^{1} \mathrm{H}$ NMR $\left(400 \mathrm{MHz}, \mathrm{CDCl}_{3}, \delta_{\mathrm{H}}\right): 7.81(\mathrm{~d}, 2 \mathrm{H}, J=8.0 \mathrm{~Hz})$, $7.62(\mathrm{t}, 1 \mathrm{H}, J=8.0 \mathrm{~Hz}$ ), 7.56 (br. s "in part merged with peak at 7.62", $2 \mathrm{H}, \mathrm{NH}), 5.28(\mathrm{~m}, 4 \mathrm{H},-\mathrm{CH}=\mathrm{CH}-), 2.29(\mathrm{t}$, $\left.4 \mathrm{H}, J=7.5 \mathrm{~Hz}, \mathrm{CH}_{2}-\mathrm{CO}\right), 2.12\left(\mathrm{~s}, 3 \mathrm{H},-\mathrm{CH}_{3}\right), 1.95(\mathrm{~m}$, $\left.4 \mathrm{H},-\mathrm{CH}_{2}-\mathrm{CH}=\mathrm{CH}-\mathrm{CH}_{2}-\right), 1.64\left(\mathrm{~m}, 2 \mathrm{H}, \mathrm{CH}_{2}-\mathrm{CH}_{2}-\mathrm{CO}\right)$, 1.22 (br.s, $20 \mathrm{H}$, chain- $\mathrm{CH}_{2}$ ), 0.80 (dist.t, 3H, terminal $\left.\mathrm{CH}_{3}\right) .{ }^{13} \mathrm{C}$ NMR $\left(\mathrm{CDCl}_{3}\right.$, proton decoupled, $\left.\delta_{\mathrm{C}}\right): 171.75$, $168.62,149.48,140.83,130,129.83,128.80,127.68$, $109.44,37.73,31.90,31.52,29.32,27.20,25.33,24.66$, 22.62, 14.10. ESI/MS $(\mathrm{m} / \mathrm{z}):(\mathrm{M}+\mathrm{H})^{+}$calcd. For $\mathrm{C}_{25} \mathrm{H}_{41} \mathrm{~N}_{3} \mathrm{O}_{2}$ : 416.588; Found: 416.4

\section{$\mathrm{N}$-(6-Undec-10-enamidopyridine-2-yl) octadec-9-enamide} ( $6 \boldsymbol{b})$

White solid, yield $=60 \%$, m.p. $=95{ }^{\circ} \mathrm{C}$, IR $(\mathrm{KBr}$, $\mathrm{cm}^{-1}$ ): 3,313, 2,920, 2,853, 1,670, 1,587, 1,519. ${ }^{1} \mathrm{H}$ NMR $\left(400 \mathrm{MHz}, \mathrm{CDCl}_{3}, \delta_{\mathrm{H}}\right): 7.91(\mathrm{~d}, 2 \mathrm{H}, J=8.0 \mathrm{~Hz}), 7.71(\mathrm{t}$, $1 \mathrm{H}, J=8.0 \mathrm{~Hz}), 7.57(\mathrm{~s}, 2 \mathrm{H}, \mathrm{NH}), 5.82\left(\mathrm{tdd}, 1 \mathrm{H}, \mathrm{JH}^{-}{ }^{9-}\right.$ $\mathrm{CH}_{2}=6.6 \mathrm{~Hz}, \quad J_{\mathrm{H}-\mathrm{Hz}}=10.2 \mathrm{~Hz}, \quad J_{\mathrm{H}-\mathrm{HE}}=17.1 \mathrm{~Hz}$, $\left.\mathrm{CH}_{2}=\mathrm{CH}-\right), 5.35(\mathrm{~m}, 2 \mathrm{H},-\mathrm{CH}=\mathrm{CH}-), 5.0\left(\mathrm{dd}, 1 \mathrm{H}, J_{\mathrm{Hz}-}\right.$ $\left.\mathrm{H}=10.2 \mathrm{~Hz}, J_{\mathrm{Hz}-\mathrm{HE}}=2.6 \mathrm{~Hz}, \mathrm{H}_{\mathrm{z}} \mathrm{C}=\mathrm{CH}-\right), 4.94(\mathrm{dd}$, $\left.1 \mathrm{H}, \quad J_{\mathrm{HE}-\mathrm{H}}=17.1 \mathrm{~Hz}, \quad J_{\mathrm{HE}-\mathrm{Hz}}=2.6 \mathrm{~Hz}, \quad \mathrm{H}_{\mathrm{E}} \mathrm{C}=\mathrm{CH}-\right)$, $2.38\left(\mathrm{t}, 4 \mathrm{H}, J=7.0 \mathrm{~Hz}, \mathrm{CH}_{2}-\mathrm{CO}\right), 2.0\left(\mathrm{~m}, 4 \mathrm{H},-\mathrm{CH}_{2}-\right.$ $\left.\mathrm{CH}=\mathrm{CH}-\mathrm{CH}_{2}-\right), 1.73$ (m, 4H, $\mathrm{CH}_{2}-\mathrm{CH}_{2}-\mathrm{CO}$ ), 1.34 (br.s, $28 \mathrm{H}$, chain- $\mathrm{CH}_{2}$ ), 0.90 (dist.t, $3 \mathrm{H}$, terminal- $\mathrm{CH}_{3}$ ). ${ }^{13} \mathrm{C}$ NMR $\left(\mathrm{CDCl}_{3}\right.$, Proton decoupled, $\left.\delta_{\mathrm{C}}\right)$ : 171.51, 149.43, 140.86, 139.15, 130, 129.70, 114.18, 109.36, 37.86, 33.77, 29.27, 29.16, 29.05, 28.89, 25.33, 14.32. ESI/MS $(\mathrm{m} / \mathrm{z})$ : $(\mathrm{M}+\mathrm{H})^{+}$calcd. For $\mathrm{C}_{34} \mathrm{H}_{56} \mathrm{~N}_{3} \mathrm{O}_{2}$ : 539.792; Found: 539.2

Synthesis of $(\mathbf{8})$

A typical process involves the addition of $\mathbf{2} \mathbf{b}(5 \mathrm{~mm})$ in dry THF (10 mL) to the stirred solution of 2-aminopyridine (7) $(5 \mathrm{~mm})$ and triethylamine $(5 \mathrm{~mm})$ in dry THF $(50 \mathrm{~mL})$. The reaction mixture was stirred overnight at room temperature (Scheme 3). The crude product obtained after workup was further purified by column chromatography and characterized by spectral analysis.

\section{$N$-pyridine-2-yl-hexadecanamide (8)}

White solid, yield $=80 \%$, m.p. $=90-91{ }^{\circ} \mathrm{C}$, IR $(\mathrm{KBr}$, $\mathrm{cm}^{-1}$ ): 3,353, 2,916, 2,849, 1,686, 1,579, 1,531. ${ }^{1} \mathrm{H}$ NMR $\left(400 \mathrm{MHz}, \mathrm{CDCl}_{3}, \delta_{\mathrm{H}}\right): 8.53(\mathrm{~s}, 1 \mathrm{H}, \mathrm{NH}), 8.18(\mathrm{~m}, 2 \mathrm{H}), 6.91$ $(\mathrm{m}, 1 \mathrm{H}), 6.95(\mathrm{~m}, 2 \mathrm{H}), 2.31\left(\mathrm{t}, 2 \mathrm{H}, J=7.4 \mathrm{~Hz}, \mathrm{CH}_{2} \mathrm{CO}\right)$, 1.64 (m, $2 \mathrm{H}, \mathrm{CH}_{2}-\mathrm{CH}_{2}-\mathrm{CO}$ ), 1.24 (br.s, $11 \mathrm{H}$, chain- $\mathrm{CH}_{2}$ ), 0.80 (dist.t, $3 \mathrm{H}$, terminal- $\left.\mathrm{CH}_{3}\right) \cdot{ }^{13} \mathrm{C} \mathrm{NMR}\left(\mathrm{CDCl}_{3}\right.$, Proton decoupled, $\delta \mathrm{C})$ : $171.99,151.65,147.46,138.52,119.58$, $114.23,37.78,31.92,29.69,29.66,29.64,29.60,29.45$, 29.35, 29.22, 25.39, 22.69, 14.11. ESI/MS $(\mathrm{m} / \mathrm{z}):(\mathrm{M}+\mathrm{H})^{+}$ calcd. For $\mathrm{C}_{23} \mathrm{H}_{40} \mathrm{~N}_{2} \mathrm{O}$ : 361.553; Found: 361.4

\section{Self-assembly}

For the formation of self-assembled morphologies of compounds (3a-c, 6a-b, 8), it was dissolved in methanol $(3 \mathrm{~mL}, 3 \mathrm{mg}$ ) followed by heating to get transparent solution. To this was added pure water (3-4 mL) and the solution was heated at $65-70{ }^{\circ} \mathrm{C}$ for $1 \mathrm{~h}$ while the solution slowly became cloudy. The dispersion was then slowly cooled to room temperature. For the dispersion of nanoparticles, sonication was carried out using FAST-CLEAN ultrasonic cleaner for $1 \mathrm{~h}$. The disperse sample appeared as white aggregates and remain stable over several months.

\section{Structural characterization}

NMR spectroscopy, mass spectroscopy and FT-IR spectroscopy

${ }^{1}$ H-NMR spectra were recorded with a BRUKER, AVANCE II 400 NMR spectrometer (Fallanden, Switzerland) at (400 MHz) in $\mathrm{CDCl}_{3}$, using TMS as internal standard. Chemical shifts $(\delta)$ are quoted in $\mathrm{ppm}$ and coupling constant $(J)$ are given in $\mathrm{Hz}$ and ${ }^{13} \mathrm{C}-\mathrm{NMR}$ spectrum was recorded at $(100 \mathrm{MHz})$ in $\mathrm{CDCl}_{3}$ with $\mathrm{CDCl}_{3}(\delta=77.00)$. The mass spectra were obtained on LC-MS spectrometer Model Q-TOF Micro waters. FTIR spectra were recorded on Perkin Elmer FT-IR spectrometer (Singapore).

\section{Fluorescence spectroscopy}

Fluorescence spectra were recorded on HITACHI F-2500 Fluorescence spectrometer (Centro Financeiro, Macau). The samples were analyzed in quartz cuvettes of $1 \mathrm{~mm}$ path length with an excitation at $350 \mathrm{~nm}$ using spectra grade $\mathrm{CHCl}_{3}$.

\section{Scanning electron microscopy}

SEM images were taken on JEOL JSM 6510LV scanning electron microscope (Tokyo, Japan). A small portion of the solid sample was attached to the holder using a conductive adhesive carbon tape. Prior to examination, the compounds were coated with a thin layer of gold. 


\section{Transmission electron microscopy}

A JEOL JEM 2100 transmission electron microscope (Tokyo, Japan) was used. The TEM sample was dispersed in water by ultrasonication and then pipette onto coppercoated grids.

\section{Sonication}

It was carried out by using FAST-CLEAN ultrasonic cleaning system (LIFE-CARE EQUIPMENTS Pvt. Ltd. India).

Acknowledgments We wish to give special thanks to the Chairman, Department of Chemistry, AMU, Aligarh, for providing necessary facilities and Sophisticated Analytical Instrumentation Facility (SAIF) Panjab University, Chandigarh for recording ${ }^{1} \mathrm{H}$ NMR, ${ }^{13} \mathrm{C}$ NMR and mass spectra. We are also grateful to the University Sophisticated Instrument Facility (USIF), AMU, Aligarh for providing SEM and TEM images.

Open Access This article is distributed under the terms of the Creative Commons Attribution License which permits any use, distribution, and reproduction in any medium, provided the original author(s) and the source are credited.

\section{References}

1. Cao, M., Hu, C., Wang, Y., Guo, Y., Guo, C., Wang, E.: A controllable synthetic route to $\mathrm{Cu}, \mathrm{Cu}_{2} \mathrm{O}$, and $\mathrm{CuO}$ nanotubes and nanorods. Chem. Commun. 15, 1884-1885 (2003)

2. Wei, Z., Wan, M.J.: Synthesis and characterization of self-doped poly (aniline-co-aminonaphthalene sulfonic acid) nanotubes. Appl. Polym. Sci. 87, 1297-1301 (2003)

3. Mo, M., Zeng, J., Liu, X., Yu, W., Zhang, S., Qian, Y.: Controlled hydrothermal synthesis of thin single-crystal tellurium nanobelts and nanotubes. Adv. Mater. 14, 1658-1662 (2002)

4. Zhang, Q., Gao, L., Sun, J., Zheng, S.: Preparation of long $\mathrm{TiO}_{2}$ nanotubes from ultrafine rutile nanocrystals. Chem. Lett. 2, 226-232 (2002)

5. Schnur, M.: Lipid tubules: a paradigm for molecularly engineered structures. J. Sci. 262, 1669-1676 (1993)

6. John, G., Masuda, M., Okada, Y., Yase, K., Shimizu, T.: Nanotube formation from renewable resources via coiled nanofibers. Adv. Mater. 13, 715-718 (2001)

7. John, G., Jung, J.H., Minamikawa, H., Yoshida, K., Shimizu, T.: Morphological control of helical solid bilayers in high-axial-ratio nanostructures through binary self-assembly. Chem. Eur. J. 8, 5494-5500 (2002)

8. Jung, J.H., Kobayashi, H., Masuda, M., Shimizu, T., Shinkai, S.: Helical ribbon aggregate composed of a crown-appended cholesterol derivative which acts as an amphiphilic gelator of organic solvents and as a template for chiral silica transcription. J. Am. Chem. Soc. 123, 8785-8789 (2001)

9. Terech, P., de Geyer, A., Struth, B., Talmon, Y.: Self-assembled monodisperse steroid nanotubes in water. Adv. Mater. 14, 495-498 (2002)

10. Schmutz, M., Michels, B., Marie, P., Krafft, M.P.: Fluorinated vesicles made from combinations of phospholipids and semifluorinated alkanes. Direct experimental evidence of the location of the semifluorinated alkane within the bilayer. Langmuir $\mathbf{1 9}$, 4889-4894 (2003)

11. John, G., Vemula, P.K.: Design and development of soft nanomaterials from biobased amphiphiles. Soft Matter 2, 909-914 (2006)

12. John, G., Mason, M., Ajayan, P.M., Dordick, J.S.: Lipid-based nanotubes as functional architectures with embedded fluorescence and recognition capabilities. J. Am. Chem. Soc. 126, 15012-15013 (2004)

13. Vemula, P.K., Li, J., John, G.: Enzyme catalysis: tool to make and break amygdalin hydrogelators from renewable resources, a delivery model for hydrophobic drugs. J. Am. Chem. Soc. 128, 8932-8938 (2006)

14. Jadhav, S.R., Vemula, P.K., Kumar, R., Raghavan, S.R., John, G.: Sugar-derived phase-selective molecular gelators as model solidifiers for oil spills. Angew. Chem. Int. Ed. 49, 7695-7698 (2010)

15. Kameta, N., Masuda, M., Minamikawa, H., Mishima, Y., Yamashita, I., Shimizu, T.: Functionalizable organic nanochannels based on lipid nanotubes, encapsulation and nanofluidic behavior of biomacromolecules. Chem. Mater. 19, 3553-3560 (2007)

16. Atwood, J.L., Barbour, L.J., Jerga, A.: Organization of the interior of molecular capsules by hydrogen bonding. PNAS 99, 4837-4841 (2002)

17. Kameta, N., Minamikawa, H., Masuda, M.: Supramolecular organic nanotubes, how to utilize the inner nanospace and the outer space. Soft Matter 7, 4539-4561 (2011)

18. Martin, C.R., Kohli, P.: The emerging field of nanotube biotechnology. Nat. Rev. Drug Discov. 2, 29-37 (2003)

19. Wakasugi, A., et al.: Organic nanotubes for drug loading and cellular delivery. Int. J. Pharm. 413, 271-278 (2011)

20. Lo, P.K., et al.: Loading and selective release of cargo in DNA nanotubes with longitudinal variation. Nat. Chem. 2, 319-328 (2010)

21. Ding, W., et al.: Hybrid organic nanotubes with dual functionalities localized on cylindrical nanochannels control the release of doxorubicin. Adv. Health. Mater. 1, 699-706 (2012)

22. Losic, D., Simovic, S.: Self-ordered nanopore and nanotube platforms for drug delivery applications. Expert Opin. Drug Deliv. 6, 1363-1381 (2009)

23. Kameta, N., Masuda, M., Shimizu, T.: Soft nanotube hydrogels functioning as artificial chaperones. ACS Nano 6, 5249-5258 (2012)

24. Ji, Q., Shimizu, T.: Chemical synthesis of transition metal oxide nanotubes in water using an iced lipid nanotube as a template. Chem. Commun. 35, 4411-4413 (2005)

25. Hoyer, P.: Semiconductor nanotube formation by a two-step template process. Adv. Mater. 8, 857-859 (1996)

26. Pradhan, S.K., Reucroft, P.J., Yang, F.Q., Dozier, A.: Growth of $\mathrm{TiO} 2$ nanorods by metalorganic chemical vapor deposition. J. Cryst. Growth 256, 83-88 (2003)

27. Kubota, S., Johkura, K., Asanuma, K., Okouchi, Y., Ogiwara, N., Sasaki, K., Kasuga, K.: Titanium oxide nanotubes for bone regeneration. J. Mater. Sci. Mater. Med. 15, 1031-1035 (2004)

28. Uchida, S., Chiba, R., Tomiha, M., Masaki, N., Shirai, M.: Application of titania nanotubes to a dye-sensitized solar cell. Electrochemistry 70, 418-420 (2002)

29. Berthier, D., Buffeteau, T., Leger, J.-M., Oda, R., Huc, I.: From chiral counterions to twisted membranes. J. Am. Chem. Soc. 124, 13486-13494 (2002)

30. Cheng, J.S., Kopta, S., Stevens, R.C.: Modulating artificial membrane morphology: $\mathrm{pH}$-Induced chromatic transition and nanostructural transformation of a bolaamphiphilic conjugated polymer from blue helical ribbons to red nanofibers. J. Am. Chem. Soc. 123, 3205-3213 (2001) 
31. Spector, M.S., Singh, A., Messersmith, P.B., Schnur, J.M.: Chiral self-assembly of nanotubules and ribbons from phospholipid mixtures. Nano Lett. 1, 375-378 (2001)

32. Spector, M.S., Price, R.R., Schnur, J.M.: Chiral lipid tubules. Adv. Mater. 11, 337-340 (1999)

33. Xia, Y., Whitesides, G.M.: Softlithographie. Angew. Chem. 110, 568-594 (1998)

34. Balachandran, V.S., Jadhav, S.R., Vemul, P.K., John, G.: Recent advances in cardanol chemistry in a nutshell from a nut to nanomaterials. Chem. Soc. Rev. 42, 427-438 (2013)

35. Selinger, J.V., Spector, M.S., Schnur, J.M.: Theory of selfassembled tubules and helical ribbons. J. Phys. Chem. B 105(30), 7157-7169 (2001)

36. Pouget, E., Fay, N., Dujardin, E., et al.: Elucidation of the selfassembly pathway of lanreotide octapeptide into $\beta$-sheet nanotubes, role of two stable intermediates. J. Am. Chem. Soc. 132, 4230-4241 (2010)

37. Guo, C., Luo, Y., Zhou, R., Wei, G.: Probing the self-assembly mechanism of diphenylalanine-based peptide nanovesicles and nanotubes. ACS Nano 6, 3907-3918 (2012)

38. Cheng, Q., Yamamoto, M., Stevens, R.C.: Amino acid terminated polydiacetylene lipid microstructures, morphology and chromatic transition. Langmuir 16, 5333-5342 (2000)

39. Shimizu, T., Masuda, M., Minamikawa, H.: Supramolecular nanotube architectures based on amphiphilic molecules. Chem. Rev. 105, 1401-1443 (2005)

40. Ryan, D.M., Anderson, S.B., Nilsson, B.L.: The influence of sidechain halogenation on the self-assembly and hydrogelation of Fmoc-phenylalanine derivatives. Soft Matter 6, 3220-3231 (2010)

41. Ryan, D.M., Doran, T.M., Nilsson, B.L.: Stabilizing self-assembled Fmoc-F5-Phe hydrogels by co-assembly with PEG-functionalized monomers. Chem. Commun. 47, 475-477 (2011)

42. de Loos, M., Feringa, B.L., van Esch, J.H.: Design and application of self-assembled low molecular weight hydrogels. Eur. J. Org. Chem. 3615-3631 (2005)

43. Gao, Y., Zhao, F., Wang, Q., Zhang, Y., Xu, B.: Small peptide nanofibers as the matrices of molecular hydrogels for mimicking enzymes and enhancing the activity of enzymes. Chem. Soc. Rev. 39, 3425-3433 (2010)

44. Jeong, Y., Hanabusa, K., Masunaga, H., Akiba, I., Miyoshi, K., Sakurai, S., Sakurai, K.: Solvent/gelator interactions and supramolecular structure of gel fibers in cyclic bis-urea/primary alcohol organogels. Langmuir 21, 586-594 (2005)

45. Hirst, A.R., Escuder, B., Miravet, J.F., Smith, D.K.: High-tech applications of self-assembling supramolecular nanostructured gel-phase materials: from regenerative medicine to electronic devices. Angew. Chem. Int. Ed. 47, 8002-8018 (2008)

46. Koley, P., Drew, M.G.B., Pramanik, A.: Salts responsive nanovesicles through pi-stacking induced self-assembly of backbone modified tripeptides. J. Nanosci. Nanotechnol. 11, 6747-6756 (2011)

47. Palmer, L.C., Stupp, S.I.: Molecular self-assembly into onedimensional nanostructures. Acc. Chem. Res. 41, 1674-1684 (2008)

48. Leenders, C.M., Albertazzi, L., Mes, T., Koenigs, M.M., Palmans, A.R., Meijer, E.W.: Supramolecular polymerization in water harnessing both hydrophobic effects and hydrogen bond formation. Chem. Commun. 49, 1963-1965 (2013)

49. Ziserman, L., Lee, H.-Y., Raghavan, S.R., Mor, A., Danino, D.: Unraveling the mechanism of nanotube formation by chiral selfassembly of amphiphiles. J. Am. Chem. Soc. 133, 2511-2517 (2011)

50. Xie, J., Qiu, H., Che, S.: Handedness inversion of chiral amphiphilic molecular assemblies evidenced by supramolecular chiral imprinting in mesoporous silica assemblies. Chem. Eur. J. 18, 2559-2564 (2012)

51. Zujovic, Z.D., Laslau, C., Bowmaker, G.A., Kilmartin, P.A., Webber, A.L., Brown, S.P., Travas-Sejdic, J.: Role of aniline oligomeric nanosheets in the formation of polyaniline nanotubes. Macromolecules 43, 662-670 (2010)

52. Reches, M., Gazit, E.: Molecular self-assembly of peptide nanostructures: mechanism of association and potential uses. Curr. Nanosci. 2, 105-111 (2006)

53. Iijima, S.: Helical microtubules of graphitic carbon. Nature 354, 56-58 (1999)

54. Iijima, S., Ichihashi, T.: Single-shell carbon nanotubes of 1-nm diameter. Nature 363, 603-605 (1993)

55. Cai, R., Chen, J., Yang, D., Zhang, Z., Peng, P., et al.: Solvothermal-induced conversion of one-dimensional multilayer nanotubes to two-dimensional hydrophilic $\mathrm{VO}_{x}$ nanosheets: synthesis and water treatment application. Appl. Mater. Interfaces 5, 10389-10394 (2013)

56. Kosynkin, D.V., Higginbotham, A.L., Sinitskii, A., Lomeda, J.R., Dimiev, A., Price, B.K., Tour, J.M.: Longitudinal unzipping of carbon nanotubes to form graphene nanoribbons. Nature $\mathbf{4 5 8}$, 872-876 (2009)

57. Koshkakaryan, G., Jiang, P., Altoe, V., Cao, D., Klivansky, L.M., Zhang, Y., Chung, S., Katan, A., Martin, F., Salmeron, M., Ma, B., Aloni, S., Liu, Y.: Multilayered nanofibers from stacks of single-molecular thick nanosheets of hexakis(alkoxy) triphenylenes. Chem. Commun. 46, 8579-8581 (2010)

58. Greaves, M.D., Rotello, V.M.: Model systems for flavoenzyme activity, specific hydrogen bond recognition of flavin in a silicate sol-gel. J. Am. Chem. Soc. 119, 10569-10572 (1997)

59. Khalil, M.M.H., De Schryver, F.C., Keller, H., Lehn, J.-M.: Fluorescence quenching in molecular recognition by hydrogen bonding. Supramol. Sci. 2, 175-182 (1995) 